\title{
THE IMPACT AND PUBLIC'S PERCEPTIONS ON THE TURNING OF TAJWID LAKE INTO A TOURIST ATTRACTION
}

\author{
By \\ Anggi Arrahman ${ }^{1}$, Achmad Hidir ${ }^{2}$ \\ ${ }^{1}$ Anthropology FISIP, Andalas University, Indonesia \\ ${ }^{2}$ Sociology FISIP, University of Riau, Indonesia \\ Email: 1 anggiarrahman0219@gmail.com,
}

\begin{tabular}{l}
\hline \hline Article Info \\
\hline ArticleHistory: \\
Received:11-10-21 \\
Revised : 17-11-21 \\
Accepted: $26-11-2021$
\end{tabular}

Keywords:

Tajwid Lake, Attraction, Economy

Corresponding Author:

\begin{abstract}
This research was aimed to determine the public's perceptions toward the attraction of Tajwid Lake. This research was also to describe the impact of Tajwid Lake attraction on local communities.The methodology used in this research was qualitative method. The data source in this research was consisted of primary and secondary data. Data collecting technique used in this research were participatory observation, in-depth interview, documentation and literature review. This research was conducted for two months. The results of the study indicated that the turning of Tajwid Lake into a tourist spot cannot be separated from various problems that cause the various public's perceptions, both pros and cons. The impact of turning Tajwid Lake into a tourist spot is the presence of a recreation area for the community and providing space to increase income such as selling and providing services for tourists so that it can help the community's economy. However, it also has a negative impact on the community, especially those who make a living as fishermen, it because Tajwid Lake was place for fishermen to get their fish. Since Tajwid Lake became a tourist spot, it has been difficult to get the fish due to the dredging of the lake for tourism purposes, as well as restrictions for fishermen looking for fish in the lake to avoid the interfere with tourist activities. It caused the fishermen losing their place to get fish. Therefore at the time they looked for fish to go far up the river, and reduced the catches which have an impact on their economy.
\end{abstract}

This is an open access article under the CC BY-SA license.

Anggi Arrahman

Anthropology FISIP,Andalas University, Indonesia

Email: anggiarrahman0219@gmail.com

\section{INTRODUCTION}

Tourism development has been one of the most important sectors in development of Indonesia, related to the natural wealth that is spread throughout Indonesia. The existence of natural resources such as hills, rivers, forests, mountains, lakes and seas certainly have the potential to be developed into a tourist attraction. According to Law No. 10 of 2009, Tourism is a variety of tourism activities and is supported by various facilities and services provided by the community, businessmen, the Central and Regional Governments. Tourism has been proven to be able to encourage economic progress in Indonesia because tourism can provide job opportunities and business opportunities for everyone.

According to Surwardjoko (in Jayanti, 2019) tourism development is a series of efforts to create integration in the use of various tourism resources and integrate all forms of aspects that are directly or indirectly related to the continuity of tourism development. There are several types of development, they are: (1) A totally new purpose, such as build the attractions on the sites that were previously used as attractions; (2) new purposes, such as develop attractions on sites that have previously been used as attractions; (3) totally new developments, such as the existence of attractions built to attract more visitors and to enable these attractions to reach a wider market by reaching new markets; (4) new developments in attractions aimed at improving visitor facilities or anticipating increased secondary 
expenditure by visitors; and (5) the creation of new activities or stages of activities that move from one place to another where these activities require modification of buildings and structures.

At the present time, tourism attraction keeps to develop in various forms such as natural attractions, cultural attractions, and human-made attractions. Indonesia is famous for its natural beauty which is spread in many regions, this can be a capital for each region in managing the natural beauty in to tourist attraction.

Riau is one of the provinces that carried out the development in the tourism sector. Almost all districts in Riau have tourism potential and are currently developing the tourism, such as natural attraction, cultural attraction, even artificial attraction that follows the times. Pelalawan Regency is one of the regencies in Riau Province which has the potential for tourism attraction spread in several areas. Some of the tourism potentials that have been successfully orbited into tourist attractions include Bono Waves as a surfing tourist destination located in Teluk Meranti District, Lake Betung as cultural tourism located in Pangkalan Kuras District, Teso Nilo National Park as a natural tourism destination that is located in Langgam District.

Another tourism potential in Langgam District is Tajwid Lake. Specifically, Tajwid Lake is located in Langgam Village, Langgam District, Pelalawan Regency. The result of research by Febriani (2019), the Tajwid Lake area has the potential to be developed into a tourist spot, and become a tourist destination for local and foreign tourists. The Tajwid Lake tourist area has qualified potentials to be used as nature-based tourism, because of the large number of flora and fauna, the potential for beauty and uniqueness in nature such as having a cape in the Tajwid Lake area. Lake Tajwid has a stunning natural beauty so that the lake is used as a place of recreation or tourist attractions. Tajwid Lake was inaugurated as a tourist spot in 2015.

Discussion of the development of the tourism sector, it should be aims to encourage the economy towards a better progression, as the tourism sector has so far been a strategic sector because it can contribute to economic progress, create jobs, develop investment, increase people's income, as well as state financial revenues (Apriani, 2018). According to Pitana (in Hary Hermawan, 2016), tourism developments will directly involve the community, thus bringing various impacts on the local community, both positive and negative impacts. In general, people view that tourism developments in an area is considered successful if it has a good economic impact on the community itself.

Pitana (2009) in Hary Hermawan (2016), suggests that the impact of tourism on economic conditions is categorized into eight categories, namely the impact on foreign exchange earnings, the impact on people's income, the impact on employment opportunities, the impact on the distribution of benefits or profits, the impact on ownership and community (economic) control, impact on development in general, and impact on government revenues. Therefore, turning the Tajwid Lake into a tourist spot is expected to be a main progress for the regional economy, especially Langgam Village, as the tourism sector has been able to provide jobs for the community such as working in the management section, providing services for tourists, selling, and the others only if the tourism development and management is carried out properly.

The utilization of natural potential used as tourist attractions is a good step in utilizing natural resources for development. Besides, it should not be forgotten that people in general also depend on natural resources around them to fulfill their daily needs. Thus, the use of natural resources to be developed into tourism requires mature consideration so that the impact of the development is perceived thoroughly by all community. According to Spillane (Apriani, 2018) the development of the tourism sector will be related to socio-cultural, political, and economic aspects that are directed at improving the welfare of the community. In the developments of the tourism sector, it is necessary to have a good assessment and analysis in order to have a positive impact in accordance with what is expected. The development of the tourism sector is also inseparable from negative impacts if the tourism development is not properly assessed for its impacts such as environmental damage and pollution, changes in social norms, excessive exploitation of natural resources so that it can damage the quality of biodiversity and ecosystems (Yanti. et al 2020).

Based on the background above, this study aims to determine the impact and public's perceptions on the attraction of Tajwid Lake.

\section{RESEARCH METHOD}

This research used qualitative method, the researcheris directly to Langgam Village, Pelalawan Regency, Riau Province where the Tajwid Lake tourist attraction is located.This research was conducted for two months, start from August, $18^{\text {th }}$ until October, $18^{\text {th }} 2021$. This research was aimed to describe the reality exists in the community about how the impact and their perception toward the attraction of Tajwid Lake.

The data source in this research consisted of primary and secondary data. Primary data sources are basic data or main data in research which is the pure result of data obtained from research subjects in the field. Secondary 
International Journal of Social Science (IJSS)

Vol.1 Issue.4 December 2021, pp: 415-422

ISSN: 2798-3463 (Printed) | 2798-4079 (Online)

DOI:https://doi.org/10.53625/ijss.v1i4.719

data sources are supporting or complementary data. such as data obtained from local government as well as from literature related to the research. Data collection techniques in this study are participatory observation, in-depth interviews, documentation and literature review.

\section{RESULT AND DISCUSSION}

3.1. General Description of Research Sites

3.1.1. General Description of Research Location

Langgam Village is located in the Langgam District, Pelalawan Regency. The distance from Langgam Village from the provincial capital of Pekanbaru is approximately $67 \mathrm{~km}$ with a distance of about 1.5-2 hours using public transportation, and the distance from the capital city of Pangkalan Kerinci Regency is approximately $40 \mathrm{~km}$ with a distance of about 40 minutes. Administratively, the boundaries of Langgam Village are in the north with Lubuk Ogong Village, in the south with Pulling Village, in the west with Tambak Village, in the east with Rantau Baru Village.

Langgam village in its history had several names before settling under the name Langgam. Formerly, named Ranah Macang Pandak after that it changed to Bukit Bandaro Bonsu, changed again to Apung Paminggih Lauih, then changed its name again to Negeri Ranah Tanjung Bunga, when it was named Negeri Ranah Tanjung Bunga this area was led by one of those in power at Kampar, that was Datuk Onggeh Bomban, until the Pelalawan Kingdom era, the name of the Land of Tanjung Bunga changed to Langgam. At that time Langgam was led by Wazir Datuk Engku Raja Lela Putra.

Giving the Langgam's name to this area also has a history. Formerly, Langgam was a stopover for people who would go upstream or downstream the river. Their stop was in the old residential area where at that time there was a large Langgam tree. So that people know this area as Langgam, and the name is acquainted until now. After independence of Indonesia, the status of the Kingdom no longer existed, and Langgam had the status of Kenegerian, then it turned into a Village that is led by the Village Head, then, in 1980, Langgam Village was upgraded to Langgam Village where Langgam is also the only village in Langgam District.

Langgam Village is located on the near of the Kampar River, so that the majority of the community's livelihood is as a fisherman. In addition, the community also makes a living as farmers in rubber plantations, oil palm plantations, traders, working in companies, and the government sector. Langgam Village, which is located in the sub-district capital, makes development in various sectors quite fast, one of which is development in the tourism sector. Development in the tourism sector can be seen with the presence of Tajwid Lake as a tourist spot in Langgam.

\subsubsection{General Description of the Attraction of Tajwid Lake}

Tajwid Lake is not the same with general lake. The lake is a tributary which in the local language people call it the asylum of the Kampar River. Tajwid Lake is the largest river of the 14 basins' river in Langgam Village. The location of Lake Tajwid is in Langgam Village, precisely to the left of the Tuo Langgam village settlement if it from the upstream direction of the Kampar River.

Before it called as Tajwid Lake, it was originally named Toluk Kojuik Lake and also Kajuik Lake. The name is inseparable from history, formerly the lake was called Toluk Kojuik because on the lake there is an island which people call it toluk, while the name kojuik comes from the area of the island where there used to be a large tree called the dice tree so the people named the lake as Toluk Kojuik. The other one is called Kajuik Lake, where previously the island and the surrounding area of the lake were overgrown by sakajuik plants (the shame princes' plant) so that people called it Kajuik Lake. Furthermore, Tajwid Lake is a name that is attached to the present time, historically the central region was a place where people learned to recite the Qur'an and learn tajwid so that is the reason the lake is now called Tajwid Lake.

To Access the Tajwid Lake is about $67 \mathrm{~km}$ from the capital of Riau, with a travel time of approximately 1.5 hours and good and paved road conditions, and the distance from the capital city of Pelalawan Regency is about 40 $\mathrm{km}$ with a travel time of approximately 45 minutes through the RAPP corridor road. As well as there are two paths to access the entrance of the Tajwid Lake,

First, through the road that is on the riverbank, then enter the under the Langgam bridge, this route is the first route built by the district government and the tourism office. Passing this route, people can see the view of the Kampar River which is quite wide with dense forests on the edge along the river. At this time the road is still dirt and has not been paved. The second path is a road opened by investors who are now managers of the attraction of Tajwid Lake, the opening and construction of the road was carried out in November 2020, it was aimed to simplify and shorten the time for visitors who will visit Tajwid Lake. The entrance to the second lane is located on the edge of the 
International Journal of Social Science (IJSS)

Vol.1 Issue.4 December 2021, pp: 415-422

ISSN: 2798-3463 (Printed) | 2798-4079 (Online)

DOI:https://doi.org/10.53625/ijss.v1i4.719

highway to Langgam. This road has been equipped with a large billboard that reads the Attraction of Tajwid Lake as a sign for tourists and a form of marketing to people who do not know about Tajwid Lake. At this time the condition of this road is still under construction and has not been asphalted, but the road can already be passed by public transportation.

This Tajwid Lake tour is the same as tourist attractions in general, for every visitor who wants to travel to Tajwid Lake, the entrance fee will be charged, but the fee is relatively cheap at a price of IDR 10,000. Tajwid Lake as a tourist spot also not only presents natural scenery, there are also game rides that can be enjoyed by visitors. Such as water duck rides for IDR 25,000, flying fox for IDR 30,000, outbound rides for IDR 25,000, pontoon rides for IDR 20,000, speed boat rides for IDR 100,000/speed boat, and other rides that are under construction such as a swimming pool.

In addition, Tajwid Lake also provides other supporting facilities as tourist attractions. Like the lodging that can be rented for visitors who want to spend the night at Tajwid Lake. Furthermore, this Tajwid Lake tourist spot also provides and rents out places and stages that can be used as party's place who want to hold events at Tajwid Lake, such as community birthdays, family gatherings and other events. To hold an event at Tajwid Lake, the manager has people who can be contacted and handle all needs such as a sound system, food, and other needs that might be prepared according to the request of those who want to hold an event at Tajwid Lake. Also, there are public facilities that can be used by visitors such as prayer rooms, toilets, seats and others facilities.

\subsection{Turning the Tajwid Lake into a Tourist Place}

The existence of Tajwid Lake in Langgam Village, Langgam District, Pelalawan Regency, as the largest river sanctuary in Langgam Village with the natural beauty that made thegovernmentinterested in making Tajwid Lake as a tourist attraction which has a selling value. Turning Tajwid Lake into a tourist spot started with the Pelalawan Exotic program, where the Pelalawan Regency government strives to build a tourist destination by utilizing the natural potential that exists in Pelalawan Regency. The potential ofTajwid Lake is to be used as a tourist spot and makes the Tajwid Lake is chosen to be developed into a tourist attraction. At that time the government also tried to make Tajwid Lake as one of the outstanding tourism in Pelalawan Regency, especially in Langgam Village, with the aimsto increase regional economic income and the community from the tourism sector, andto fulfill the need for recreation and local communities to the wider community.

Langgam sub-district, which is part of the Petalangan Indigenous area, makes Tajwid Lake also part of the Petalangan customary area. The rules in the adat Petalangan are that forests, rivers, asylums or tributaries, lakesare customary property that cannot be traded but can be managed by the community. Management by the community is carried out in a customary manner, management is carried out by conducting an auction which is conducted once a year, the auction process is carried out in a traditional manner where the results obtained from the auction are used for traditional and religious needs in the community. In turning Tajwid Lake as a tourist spot requires the approval of the customary leaders in Langgam. Therefore, the holding of consensus deliberation as a step used, in making decisions regarding management and the impacts that will arise, from turning Tajwid Lake into a tourist spot.

After going through a long consensus deliberation between customary holders, sarak holders and the government which is the tali bapilin tigo, Tajwid Lake was inaugurated as a tourist spot in 2015. The deliberation held by tali bapilin tigo, namely adat holders, sarak holders and the government, resulted in a decision where adat handed over the management of Tajwid Lake to the district government with the hope that the construction and development of Tajwid Lake as a tourist spot could contribute to improving the local community's economy, regional income, and regional progress.

\subsection{The Impacts and Public's Perceptions of Tajwid Lake as Tourist Attractions}

The construction and developmentof tourism in an area must carry out a conceptualization that is in accordance with the conditions of the area and carry out stages that examine the existence of potential and relationships that exist in the tourism. This is necessary in order to facilitate the parties involved in the management and monitoring of tourism in evaluating and taking good policies for the sustainability of the tourism and the impact it has on the environment and surrounding communities.

The construction and development of tourist attractions in an area will indirectly touch the lives of the community, so that this will have an influence on the lives of community who are in the area where the tourist attractions are built. Therefore, it would be better if tourism development in the area always carried out a thorough study of what impact it would have on the community. The purpose of the construction and development of atourist attraction isto improve and advance the area and communitie's lives to be better. The thing that is always strongly related to the purpose of developing a tourist attraction in the area is the economy. Economic problems have always 
International Journal of Social Science (IJSS)

Vol.1 Issue.4 December 2021, pp: 415-422

ISSN: 2798-3463 (Printed) | 2798-4079 (Online)

DOI:https://doi.org/10.53625/ijss.v1i4.719

been a benchmark for the success of a development in the tourism sector. In the Law on Tourism No. 10 of 2009, one of the objectives of implementing tourism is to increase economic progress in order to improve the welfare and prosperity of the people, also to expand and equalize opportunities for independent business and employment and to encourage regional development. Based on those statement, the attraction of Tajwid Lake must be managed properly and carefully examine the impacts that will be caused, and involve the community so that the impact of this tourism can be felt thoroughly by various groups, according to the objectives, and with what they aspire to.

The utilizing of natural potential that exists in an area such as being used as a tourist spot, this is a good step that can be one of main progress of the community's economy. However, it requires careful assessment and consideration because in general people in fulfilling their daily needs also depend on the potential that exists in the nature around them. As known, Langgam Village is located on the edge of the Kampar River so that people in their daily activities and in fulfilling their daily needs depend on the resources available in the river, includedTajwid Lake because the lake is a tributary of the Kampar River. The people of Langgam Village, the majority of whom make a living as fishermen, of course also use and engage in fishing activities in the lake.

For people who work as a fisherman,Tajwid Lake is a source of income for them, because the lake is a place where there are lots of fish. Tajwid Lake in the Langgam community is also intended to be a place for widows as fishermen that looking for fish. This is due to the consideration that the location is easy to reach so that with the limitations that exist in these widows they can still meet the needs of daily life. The island area of the lake is a community plantation where the area is customary land that is distributed to nephews to be managed. Before being used as a tourist spot, Tajwid Lake was a place for people to carry out activities to fulfill their daily needs.

The Tajwid Lake area is an area controlled by the indigenous society of the Domo tribe. At first, the community and customary holders handed over the management of the lake and the central land area of the lake into a tourist spot to the local government. Hopefully this decision will have a good impact on improving the economy of the people in Langgam. The local government in developing and managing Tajwid Lake attraction was initially in collaboration with investors. But over time, the status of tourism management shifted to an investor and the land or island in the middle of the lake is now the private property of the investor. This private ownership has many contras in the community, because the land in the lake area is ulayat land which is distributed to the descent of the Domo tribe and cannot be traded.

At the initial status, islands and lakes became customary rights with management held by the district government. Now the management status has changed hands to an investor, who apparently also has the rights to the island located in Lake Tajwid Lake. The descents that was previously allowed to manage the island or land area on the lake, has now sold the land to the investor privately. So that private ownership by the investor makes changes in its development. Many people feel that this tourism development is not profitable at all, especially for people who work as fishermen. For the community, the development of Tajwid Lake attraction at this time does not consider the conditions and circumstances of the community, and no longer includes local communities in it.

The public's perception of Lake Tajwid as a tourist spot in Langgam Village has arisen since the first time customary holders allowed the management to be held by the district government, until now where management is held by an investor and the owner of the island is privately owned by the investor. There are even conflicts that arise over the status of private ownership on the ulayat land. Some people say the lake is fully controlled by the investor, and there are also those who say that the lake is still controlled by indigenous peoples because the lake is a communal right and only the island is controlled and not the lake. Various negative issues have developed in the community towards Tajwid Lake attraction. Several versions have been heard in the community regarding the status of private ownership. Some say that there was a government party that at that time managed to trap the nephew's son in releasing the land to the investor. There are also those who say that the island in the lake is indeed someone's private property which can be traded.

When Tajwid Lake became a tourist spot in 2015, around 35 families were fishermen, most of them widows who previously used the lake as a place for them to get fish, but now they no longer fish there. Thus, at this time they go fishing to go far to row the boat up to the upper Kampar river to get fish. The fishermen are currently complaining about this because their catch has decreased significantly since they no longer look for fish in the lake. The fishermen sometimes feel that the time and energy spent is not comparable to the catch that is not sufficient for their daily needs. In addition, when Lake Tajwid Lake was opened as a tourist spot, the government which was the manager at that time carried out dredging in the lake such as wood or tree branches that became fish nests, dredged and cleaned, so that fish are now hard to find. The dredging of the lake is carried avoid the interference of tourist activities such as duck boat games, boats and others. There was also a ban on fishermen from looking for fish to the lake because the lake has become a tourist spot, and fishing activities can interfere with tourism activities in Tajwid Lake. But now people are no longer prohibited from fishing there but must comply with the time given by the lake 
International Journal of Social Science (IJSS)

Vol.1 Issue.4 December 2021, pp: 415-422

ISSN: 2798-3463 (Printed) | 2798-4079 (Online)

DOI:https://doi.org/10.53625/ijss.v1i4.719

manager, such as fishermen may set up nets in the afternoon and the nets must be opened in the morning before the Tajwid Lake tourist attractions are opened. However, for many people who feel that there is no longer any profit in looking for fish in the lake because fish are hard to find there, the difficulty of finding fish is because the fish nests in the lake have been damaged and thrown away by tourism managers. For some people, the construction of this tourist lake has no contribution to the community, it is considered only profitable for investors who manage the tourism at this time, and detrimental to the community, especially fishermen. There are also people who consider the existence of this tourist attraction have a positive impact because it provides a place of recreation for the community and can make Langgam is recognized by outsiders because of the tourism The views and expectations of the community that arise from the impact of Lake Tajwid tourism have made Datuk Penghulu Langgam and Ninik Mamak try to change the agreement on the management of Lake Tajwid. How to get nephews involved in the management of the lake. Datuk and Ninik Mamak hope that the lake can develop into a tourist spot that has a positive impact on the whole community. Furthermore, in the management and concept of tourism, it must be discussed with Datuk and Ninik Mamak and the surrounding community, because the hope for the development of tourism in Langgam will be based on local wisdom.

The perceptions and expectations of the community that arise from the impact of Tajwid Lake attraction have made Datuk Penghulu Langgam and Ninik Mamak try to change the agreement on the management of Tajwid Lake. How to get their descendant involved in the management of the lake. Datuk and Ninik Mamak hope that the lake can develop into a tourist spot that has a positive impact on the whole community. Furthermore, in the management and concept of tourism, it must be discussed with Datuk and Ninik Mamak and the local community, because the development of touris attraction in Langgam is expected will be based on local wisdom.

\section{CONCLUSION}

The turning of Tajwid Lake as a tourist spot cannot be separated from the problems that were arise to various perceptions from the community. So far, many people felt that there was no contribution from the development of tourist attractions to the community. In addition, in the management and development of tourist attractions, there was no cooperation and communication built by the manager to the local community. So that the developments did not go according to what is expected by the community.

The construction and development of Tajwid Lake as a tourist spot had positive and negative impacts. The positive impacts that arise were the presence of recreation areas for the community and also provided space for the community for selling and providing services for tourists, so that it can help the economy of some people. Meanwhile, the negative impact caused is that local fishermen have lost the places they usually use to catch fish, so the fishermen at this time, to catch their fish, they should go far upstream. Local fishermen have lost their income economically since they lost one of the places they usually fish, namely Tajwid Lake.

Customary Leader in Langgam Village currently hope that the management of tourist attraction will involve the community, as well as the establishment of good communication between managers and indigenous societies so that the development of this attraction in the future is in accordance with what had been expected by the community. The construction and development of a tourist site will have problems if it does not get the support from the local community. The construction and development of tourist attraction will run smoothly if it gets support from the community. Therefore, in the construction and development of tourist attraction, it is necessary to involve the community so that the goals of tourism construction and development can be achieved. Community involvement is very important in the success of tourism construction and development.

\section{ACKNOWLEDGEMENTS}

Thanks to AAI Pengda Riau, SKK Migas Sumbagut and PT. Energi Mega Persada (EMP) MalacaStrait who has assisted in research funding and guidance during the research and writing of this article. This research and writing was carried out on the collaboration program of SKK MIgas - KKKS with AAI Pengda Riau.

\section{REFERENCES}

[1] Dewi Apriani Aco, 2018, "Dampak Obyek Wisata Pantai Jikomalamo Terhadap Kehidupan Sosial Ekonomi Masyarakat", Tekstual, Vol 16 (1) 2018, pp. 14-21.

[2] Yanti, Teuku Kemal Fasya, Ibrahim Chalid, 2020, "Dilema Wisata Di Kota Lhokseumawe: Studi Sosial Budaya Pada Tempat Wisata Waduk Jeulikat", Aceh Anthropological Journal, Vol 4, No. 1, 122-141, Apr 2020. 
International Journal of Social Science (IJSS)

Vol.1 Issue.4 December 2021, pp: 415-422

ISSN: 2798-3463 (Printed) | 2798-4079 (Online)

DOI:https://doi.org/10.53625/ijss.v1i4.719

[3] Ririn Febriani, Hadinoto, Enny Insusanty, 2019, "Identifikasi Potensi Untuk Pengembangan Wisata Alam Danau Tajwid di Kelurahan Langgam Kecamatan Langgam Kabupaten Pelalawan Provinsi Riau", Wahana Foresta: Jurnal Kehutanan, Vol 14 No. 1, Jan 2019.

[4] Widya Noprianty, Kusai, Trisla Warningsih, 2018, "Strategi Pengembangan Wisata Danau Kajuik Kecamatan Langgam Kabupaten Pelalawan Provinsi Riau", Jurnal Perikanan dan Kelautan, Vol 23, No. 2, pp. 54-60. Des 2018.

[5] Purwanto, Emy Sadjati, Enny Insusantry, 2019, "Persepsi Pengunjung Terhadap Daya Tarik Wisata Danau Tajwid Kecamatan Langgam Kabupaten Pelalawan", Wahana Forestra: Jurnal Kehutanan, Vol 14, No. 1 Jan 2019.

[6] Moleong, Lexy J. 1989. Metodologi Penelitian Kualitatif. PT. Remaja Rosdakarya. Bandung

[7] Undang-Undang No.10 Tahun 2009,Tentang Kepariwisataan. https://www.kemenparekraf.go.id/assetadmin/assets/uploads/media/oldfile/46361364UUTentangKepariwisataa nnet1.pdf

[8] Hary Hermawan, 2016, "Dampak Pengembangan Desa Wisata Nglanggeran Terhadap ekonomi Masyarakat Lokal”, Jurnal Pariwisata, Vol 3, No. 2. Sep 2016.

[9] Nur Purtri Jayanti, 2019, "Pengembangan Objek Wisata Pantai Gandoriah Kota Pariaman”, Pariwisata, Vol.6 , No. 2, 2019

[10] Sopa Martina, 2014, "Dampak Pengelolaan Taman Wisata Alam Kawah Putih Terhadap Kehidupan Sosial dan Ekonomi Mayarakat”, Pariwisata, Vol 1, No.2, 2014.

[11] Santi Muji Utami, 2013, "Keterlibatan Masyarakat Lokal Dalam Pengembangan Potensi wisata di Kabupaten Semarang", Forum Ilmu Sosial, Vol 40, No. 1, 2013. 
International Journal of Social Science (IJSS)

Vol.1 Issue.4 December 2021, pp: 415-422

ISSN: 2798-3463 (Printed) | 2798-4079 (Online)

DOI:https://doi.org/10.53625/ijss.v1i4.719

THIS PAGE HAS INTENTIONALLY BEEN LEFT BLANK 